\title{
CONCENTRATIONS OF ECONOMIC ENTITIES IN THE LAW OF THE EUROPEAN UNION AND THEIR CONNECTION WITH THE AGRICULTURAL SECTOR
}

\author{
Boro Krstićl \\ *Corresponding authorE-mail: boro.krstic@singidunum.ac.rs
}

\begin{abstract}
A R T I C LE I N F O
Original Article

Received: 25 November 2020

Accepted: 06 December 2020

doi:10.5937/ekoPolj2004233K

UDC 330:338.43(4-6EU)
\end{abstract}

Keywords:

competition, concentrations, companies, agriculture, market

JEL: K20, K22, K29

\begin{abstract}
A B S T R A C T
Purpose The paper should confirm that concentrations of economic entities, which perform agricultural or other activities, in addition to distorting competition, are frequent cases of competition protection on the European Union market.

Methodology The paper uses dogmatic and normative method that highlights existing legal solutions and indicate the directions of de lege ferenda solutions and method of content analysis.
\end{abstract}

Results Concentrations of business entities are playing an increasing role in the world economy and law. The process of globalization of international trade and increasing competition among businessmen, especially in the countries of the European Union, have contributed to this. Conclusions Concentrations of business entities are important in creating market monopolies and they represent means of protecting the global market.

Recommendations An important aspect of the concentration is its compatibility with the global market, otherwise, the application of temporary measures is recommended in order to restore the previous state.

(C) 2020 EA. All rights reserved.

\section{Introduction}

According to Article 4, paragraph 1. community policy is conducted in accordance with the principles of an open market economy and free competition, and the basic rules on competition are contained in Art. 81-89 EEC (Title VI, Section 1). Articles 81 and 82, which contain rules on the prohibition of cartels and on the prohibition of abuse of a dominant position (Stanivuković, 2009), are particularly relevant. Taking certain actions that lead to a change in the number of market participants, i.e. its reorganization, leads to a decrease in competitive pressure. Competition among businessmen in the global market, especially in European Union countries, has led to

1 Boro Krstić, Ph.D., Assistant Professor, Singidunum University, Faculty of Health and Business Studies, Železnička 5, 14000 Valjevo, Phone: +387 65237 072, E-mail: boro. krstic@singidunum.ac.rs, ORCID ID (https://orcid.org/ 0000-0002-9919-2422) 
the adoption of regulations within the framework of the Community acquis, which will comprehensively regulate this area, as competition from the outside, especially from the USA and Japan, has become increasingly fierce. It was therefore necessary to strike a balance between the need to strengthen economic activities for fear of overhauling the common market. In this regard, the Community institutions have, inter alia, adopted Regulation 139/2004 on merger control, Regulation 802/2004 on implementation of Regulation 139/2004, and a number of Guidelines, with particular reference to the 2007 Consolidated Jurisdictional Notice (hereinafter: The Notice). We are witnessing that the agricultural sector has been under the auspices of foreign capital in the last decade. Large state-owned agricultural chains are being purchased, so the legal regulation in use throughout the European Union is of great interest and importance to countries waiting to join this organization, and such are the countries of the Western Balkans.

The subject of this paper is the exploration of key regulations that point to the emerging forms of permitted and prohibited concentrations that appear in the common market, which may also affect countries awaiting accession to the European Union. The aim of the paper is to find the most favourable conditions for the implementation of certain forms of integration, without the result of prohibited concentrations of companies.

\section{The concept of concentration}

In recent years, we have witnessed the joint appearance of business entities in certain business operations, in order to meet the stringent requirements of the market. Joint ventures or concentrations of companies can be done in several ways, such as fusion, the purchase of parts or entire companies, or as a joint venture of two companies (Spasić, 2017). The common agricultural policy of the European Union is based on the establishment of common organisation of agricultural markets, which depending on the type of product, can have several forms: common competition rules; mandatory coordination of different national market organisations and European market organisations. The common market organisation shall be limited to the achieving the objectives of the common agricultural production and shall exclude any discrimination between producers or consumers within the union (Treaty 2010/C 83/01, art.40). Accordingly, the topic of this research relates to the organisation of the common market on the principle of competition rules (Andrei et al., 2020). The method of formation of concentrations also represents the basis for distinguishing possible types of concentrations (Ciutacu \& Chivu, 2014). The way in which the concentrations occur is also the basis for distinguishing the possible types of concentrations. In this sense, concentrations may arise through statutory changes in companies (reorganization), and by acquiring certain shares in a company, that is, by linking companies with financial participation, i.e. by acquiring one part of the shares of a certain company and gaining control in the management of the companies. While merging of companies has the character of a status change, the acquisition of participation creates different forms of connection that create subsidiaries (holding companies, concern groups and other groups). Merger is a status change within which two types of merger occur, namely merger through 
annexation and establishment (Mićović, 2010). Merger refers to a process in which one or more companies transfer their entire assets to another existing company or to a newly formed company, which issues to the shareholders of the merged companies their shares in proportion to their participation in the previous and new companies (Jevremović Petrović, 2010). On the other hand, linking companies with financial participation and gaining control in another company represent economic concentration.

The main difference between merging through financial participation and annexation is that the status change of the merger is based on the consent of the companies participating in this procedure, as well as the conclusion of contracts between the companies. However, in a purely economic takeover there is no conclusion of any contract, but shares are directly bought from the shareholders of the company being acquired (Jevremović Petrović, 2010; Odeny et al., 2020). The concentration of companies is reflected in the greater or lesser transformation of the merged and acquiring society, enabling progress and adaptation to modern economic life (Pantić et al., 2020). According to this author, such concentrations stem from the need for mergers of companies (Cheminade, 1970). EU law has favoured concentration as a form of freedom of association for market participants, but also as a way of enhancing the competitiveness of European companies' vis-à-vis non-European companies on the world market, especially large US companies (Gavric Stepanovič, 2000). Issues of the occurrence of concentrations at European Union level are governed by the norms of the Community acquis. Community acquis prescribes that concentrations include the fusion of two or more previously independent entities or parts of an enterprise, the acquisition or purchase and joint business ventures (Regulation 139/2004). Within this introductory debate and definition of concentrations, it is worth noting that Concentrations, i.e. fusions, can be horizontal, vertical and conglomerate. Horizontal fusion is the merger of companies at the same level of the production chain, as opposed to the vertical merger, which is the merger of companies at different levels of the production chain, for example the fusion of manufacturers and distributors (Chivu, 2019). Finally, conglomerate (combined) fusions are mergers of companies that are motivated by the desire to reduce costs and risks of doing business, and take place between companies with completely different business activity (Vasiljević, 2004). In EU law, all forms of integration are regarded as concentrations (Spasić, 2007), and their regulation takes place under specific regulations at EU level. Such a document is the Regulation on Concentrations (hereinafter: the Regulation), which is applicable to concentrations that have a communitarian dimension, and which is determined on the basis of the turnover of participants in it. According to the Regulation, the concentration has a communitarian dimension where the total annual turnover of all related undertakings exceeds EUR 5 billion and where the total turnover at Union level of each of at least two related undertakings exceeds EUR 250 million, unless each of the undertakings concerned generates more than two-thirds of its revenue at Union level within the same Member State (Regulation 139/2004). In the event that the concentration does not meet the conditions of Article 1 (2) of the Regulation, the concentration will have a 
communitarian dimension if the combined total annual turnover of all the undertakings concerned is more than two and a half billion euros, where in each of at least three Member States the total turnover of all related undertakings exceeds EUR100 million, where in each of the at least three Member States referred to in paragraph (b) the total turnover of each of at least two given undertakings exceeds EUR25 million and where the total turnover at Union level of each of at least two related undertakings exceeds EUR 100 million, unless each of the given companies achieves more than two-thirds of its total turnover at the level of the Union in the context of one and the same Member State (Regulation 139/2004). However, the turnover of the undertakings concerned may be calculated (i) on the basis of the turnover of those undertakings to which that undertaking has relations, which consist of the rights or powers referred to in Article 5 (4) of the Regulation, in order to determine whether the thresholds referred to in Article 1 of the Regulation are fulfilled (Commission Jurisdictional Notice, 2004). Such concentration criteria are intended to distinguish concentrations having a European dimension from concentrations of minor importance, and also these criteria indicate that concentrations are reported only if undertakings with large capital participate in it.

\section{Applicable law and jurisdiction to assess concentration}

In determining the rules to be applied to the regulation of concentrations, the starting point is the rule according to which the law of a Member State will apply to concentrations which have no communitarian dimension. However, even in situations where a particular concentration is judged to have a Communitarian character, the assessment can be transferred to the national competition authorities and vice versa. This possibility was confirmed in the Commission Notice on Case Allocation under the Referral Rules of the Merger Regulation, which emphasized that jurisdiction should only be re-attributed to another competition authority only in circumstances where the latter is more appropriate for dealing with fusion, having regard to the specific characteristics case as well as the resources and expertise available to the agency (Commission Notice, 2005). In addition, it is very important that the transfer of jurisdiction is made in a situation where there is a compelling reason for it and especially at the stage after notification of the concentration in question (Commission Notice, 2005). The concentration notification is based on a good coordination of relations between the Commission and the competent authorities of the Member States, with the Commission having the possibility to refer the notified concentration to the appropriate authorities of the Member States to assess whether it is in accordance with national law. In such a case, the Member State shall, within 15 working days of receipt of the copy of the notification, inform the Commission whether the concentration in question threatens to significantly affect competition in that country's market and whether it may create or strengthen its existing dominant position. If the Commission considers that there is a different (special) market and threats to competition in it, it may itself resolve the case in accordance with the Regulation or refer all or part of the case to the competent authorities of the Member State concerned, where the case would be resolved by applying a national Community 
acquis. In order for this possibility to be implemented, a Member State must make a corresponding request to the Commission within 15 working days of receiving a copy of the concentration notification from the Commission (Regulation 139/2004). The Commission decides whether to refer the case to the competent authorities of the Member States or to decide on the case itself. Referrals may be made only if the Member State makes an appropriate request and if the Commission determines that the conditions relating to the specificity of the market in the territory of the Member State are fulfilled, as well as the possibility of jeopardizing competition therein (Regulation 139/2004). If the conditions are not met, the Commission will inform the Member State accordingly. A Member State may appeal to the Court of First Instance against the decision of the Commission. Bearing in mind that such a solution was incorporated into the Decree at the request of Germany, it became known as the German clause. It was used in the case of Steetley plc/Tarmac, where it was a fusion between Steetly and Tarmac company, both of which had a high share of the brick and clay market in some parts of England. The Commission found that the brick market was regional in nature and that the trade in clay tiles between the UK and the rest of the Union was of low intensity, justifying such an attitude by different economic indicators. It is, therefore, considered that this is a particular market, the UK market, where such a concentration could cause adverse competitive effects. For these reasons, the Commission decided to refer the fusion case for resolution to the UK competent authority in accordance with domestic regulations (Case Steetly/Tarmac IV/M.180,1992). A Member State may take appropriate measures to protect legitimate interests not protected by the Regulation in question, such as public security, media plurality and prudential rules, and any other public interest must be transferred to the Commission by the Member State concerned. The Commission shall inform the Member State concerned of its decision within 25 working days of notification (Regulation 139/2004, Art. 21(4).). This was the procedure in the case of Newspaper Publishing, where the UK authority took steps against the fusion in question justifying such an act by preserving media plurality (Case Newspaper Publishing IV/M.423.), and in the case of Lyonnaise des Eaux SA / Northumbrian Water Group, where the UK Competition Commission applied national regulations concerning the regulation of the drinking water market. Namely, here the Commission started from the standpoint that it represented a legitimate public interest for the Member State concerned, especially given the privatization of the sector and the desire to preserve competition, that is, a sufficient number of water suppliers. This enabled the competent British body to prohibit any fusion that would exceed a certain, pre-defined level (Case N IV/M567, 1996). A Member State may take the measures necessary to protect the essential security interests of its security related to the production or trade in arms, ammunition and war material (EC Treaty 2002, art.296(1)(b)), and practice has confirmed this derogation. Thus, in the case of British Aerospace / GEC Marconi, the United Kingdom ordered the parties of the concentration not to notify the military part of the concentration in accordance with Article 296 (1) (b) of the EC Treaty, justifying such an act as essential to its security, with which the Commission agreed (Case British Aerospace/GEC Marconi, 1999) C241/8.). One or more Member States may request the 
Commission to examine any concentration which has no communitarian dimension but which affects trade between Member States or threatens to significantly distort competition within the territory of the Member State or Member States making the request (Regulation 139/2004, art. 22). This provision was introduced at the request of the Netherlands (which is why it was called the 'Dutch clause') and was motivated by a desire to meet Member States that did not have their own fusion control regulations at the time. In order for the Commission to examine the concentration in the case of a Dutch clause, it is necessary for a Member State, or others, to make a specific request to the Commission to that effect (Regulation 139/2004). One of the cases in which the Commission prohibited a concentration in accordance with the above procedure was Kesko/Tuko and the ban was enforced at the request of the Finnish Free Competition Office. Although this was not a concentration of a communitarian nature, it was found that it could have had a significant adverse effect on trade between Member States, which was sufficient for the Commission to respond positively to the request of the competent Finnish authority and to prohibit the concentration in question (Case IV/M.784). Implementing Regulation 802/2004 prescribes the form and content of the notice to the Commission, which must be complied with, because in the event that the notification has certain deficiencies (it is not complete), the Commission will not accept it. It is therefore advisable for undertakings to consult the Commission before notification in order to avoid any shortcomings in the notification, and in particular to reduce the amount of information that the notification must contain (Commission Notice, OJ 2005/C 56/04). The Commission, in accordance with Article 14 (2) (a), has the right to impose fines in the event of non-compliance with the obligation of notification (intentional or negligent), which may not exceed $10 \%$ of the total turnover of the undertakings concerned (Regulation 139/2004, art. 14(2)(a).).

\section{Control of concentration and Commission decisions}

It could be said that the ability to control concentrations is the most important characteristic of concentrations, and concerns the possibility of gaining control of another market participant after the concentration has taken place (Rakić, 2014). About that, upon receipt of the notification of the concentration, the Commission will examine whether the notification is covered by the Regulation, after which it must take the appropriate decision within 25 days (Regulation 139/2004, Art. 10(1).), so if the Commission finds that the concentration in question does not fall under the Regulation, it may decide that the concentration is not in the domain Community acquis (Regulation 139/2004, Art. 6(1)(a).). On the other hand, it may decide that the concentration in question is compatible with the common market or make the concentration compatible by accepting certain obligations by the participants (Regulation 139/2004, Art. 6(1)(b).). The Commission may also find that the concentration covered by the Regulation raises "serious doubts" about compatibility with the common market (Regulation 139/2004, Art. 10(3).). It should be borne in mind that if the concentration is found to be incompatible with the common market and the parties have already implemented the concentration, the Commission has the option of using provisional measures or even ordering the concentration to be reversed in order to regain its status. However, if 
restoration is not possible, then the Commission may take "other appropriate measures" to achieve the same objective (Provision 139/2004, art. 8.). The regulation allows for effective control of all concentrations, providing that any concentration that would significantly impede effective competition in the common market, or in a substantial part of it, should be declared incompatible with the common market (Provision 139/2004, art. 25.). Given that horizontal fusions are the most dangerous for the competitive process, the Commission has issued the Horizontal Merger Guidelines (hereinafter: the Guidelines) (Horizontal Merger Guidelines, 2004). According to these Guidelines, the creation or strengthening of a dominant position is the primary form of aforementioned impediment to effective competition in the common market, with the central issue being the determination of the relevant market. Given that the determination of the relevant market has another dimension, (product / service, geographic market) only the most significant determinants will be highlighted here (Guidelines, 2003). Procter\&Gamble vs. VP Schickedanz case has shown that the Commission pays much more attention to demand side factors (Case IV/M.430, (1994) OJ L354/32, (1994) 5 CMLR 146.). Sometimes the factors on the supply side may not be relevant, as the Nestlé / Perrier case has shown, where the Commission considered the bottled spring water market as a relevant product market, relying on manufacturers' ability to easily 'reorient' to production of another product (Case IV/M.190, (1992) OJ L356/1, (1993) 4 CMLR M17.). With regard to the relevant geographic market, the Commission has, in the case of Gencor/Lonrho (Case IV/M.619.), taken as a relevant geographic market the global market for metallic products (especially platinum) due to its wide application, high volume of trade and cheaper transport, and in the case of Shell/Montecatani the reason for wide definition of the geographic market (world market) was a character of the product, since its production required large investments in research and development (Case IV/M.269 Shell/Montecatani, 1994). Sometimes the geographic market was of a national character, or even more narrowly defined, as in the case of Nestlé/Perrier, where the Commission designated the French market as the relevant geographic market, due to relevant market factors (Case Nestlé/Perrier-see OJ, 1992). Sometimes the relevant geographic market is determined in view of the fact that the economic integration of the Member States is growing stronger and that trade barriers are eliminated, as in the case of Alcatel / Telettra (Case IV/M.42, (1991) OJ L122/48, (1991) 4 CMLR 778.) and Alcatel/AEG Cable (Case IV/M.165, Alcatel/AEG Kabel (1992) OJ C6/23.). Here, despite the large market share acquired through the merger, the Commission approved the notified concentration.

\section{Types of concentrations}

The degree of competitive relationship existing between the parties to the concentration is the basis for the division of concentrations into horizontal, vertical and conglomerate ones. The Concentration Assessment Test is common to all forms as well as the financial amounts for the Concentration Report, however, the Concentration Assessment Criteria differ, and the Guidelines for the Assessment of Horizontal Concentrations and the Guidelines for the Evaluation of Vertical and Conglomerate Concentrations have been developed, with the criteria being the most stringent for the assessment of horizontal concentrations. The different criteria for the assessment of concentrations in their 
tests also indicate the application of special rules, and the competent authorities that conduct the concentration are required to demonstrate, in each case, the adverse effects of concentration on competition. Horizontal concentrations directly (by reducing the number of competitors) influence the creation of non-competitive market structures, leading to a decrease in competition in the market. On the other hand, vertical and conglomerate concentrations can indirectly affect competition, first by establishing entrance barriers for new competitors, that is, by controlling the market entry process, which is why they are often classified into a separate group (non-horizontal concentrations), (Begović, 2002). Numerous benefits realized in horizontal and vertical concentrations are made possible by the structural links that exist in minority ownership between two market participants operating in the same or a related market, by investing equal market participants in the equity of other market participants (Begović, 2014).

\section{Horizontal concentrations}

As noted earlier, horizontal concentrations take place between business entities operating at the same level of the production or transport chain, or rather, between direct competitors in the market. After defining the relevant market, the Commission will look at the degree of market concentration, relying on both the magnitudes of the parties to the concentration and the aforementioned Herfindal-Hirschman Index. Such a view is made in the Horizontal Fusion Guidelines, which states that market shares and concentration levels give the first indication of the market structure and competitive importance of fusion participants and their competitors (Guidelines, 2003). Very large market shares, of $50 \%$ or more, can themselves be evidence of a dominant position, as opposed to a situation where the market share of the related companies does not exceed $25 \%$. In the latter case, the concentration will be deemed not to interfere with effective competition. However, in the same paragraph, the Commission points out that a market share of less than $50 \%$ and more than $25 \%$ may pose a problem, given the strength of competitors, the existence of capacity constraints, or other factors (Guidelines, 2003). Practice has shown that the Commission is sensitive when it comes to fusions involving companies producing interchangeable products, that is, substitutes, and in particular when competing manufacturers do not produce sufficiently "close" substitutes to the products of fusion participants. Thus, in the case of GE/Instrumentarium, the Commission expressed doubts as to the compatibility of the fusion companies GE and Instrumentarium, which were manufacturers of medical equipment. Given the high degree of substitution that existed between their products, the Commission concluded that the fusion in question could adversely affect competition, and ordered the companies concerned to take a number of measures to eliminate the negative effects (Case COMP/M.3083, IP/03/1193.). Similar was the case with T-Mobile/tele.ring (Case COMP/M.3916). Horizontal Fusion Guidelines predict that the reasons for banning fusion may be the inability of customers to protect themselves from price increases by changing suppliers (Horizontal Merger Guidelines, 2004), the inability of competitors to increase their deliveries (Horizontal Merger Guidelines, 2004, OJ C31/5.), but also 
the situation where fusion involves a company having a significant impact on the dynamics of competition, especially if it represents an important driver of innovation in the market (Case Boeing/McDonnell Douglas IV/M. 877, 1997). On the other hand, the assessment of horizontal fusion compatibility can be particularly helpful in assessing barriers for entering the relevant market. In this regard, the Commission may approve a concentration that includes players with an extremely large market share, provided that there is a realistic possibility of entering the market of new competitors. Nevertheless, this new market entry must be plausible, timely and sufficient to deter or counteract any potential anti-competitive effects of fusion (Horizontal Merger Guidelines, 2004). Entry is likely if it is profitable enough for a new entrant to bring additional output to the relevant market (Horizontal Merger Guidelines, 2004). At the same time, the Commission took the stand that entry into the market would be considered " timely " if it came within two years (Horizontal Merger Guidelines, 2004). Fusion in the common market can significantly impede effective competition by creating or strengthening a collective dominant position. In such a situation, companies are more likely to be able to coordinate behaviour and increase prices, even without concluding agreements or resorting to concerted practices within the meaning of Article 81 of the Treaty (Horizontal Merger Guidelines, 2004). Horizontal fusion may be granted where it is provided with efficiency, whereby the benefits of fusion to consumers outweigh any adverse competitive effects (Horizontal Merger Guidelines, 2004). Fusion can be compatible with the common market and based on a call to the so-called "Failing Firm Defence". Namely, if one of the parties to the concentration is a so-called "weakening company' and provided that the fusion does not cause deterioration in the competitive structure, the Commission may consider the fusion in question compatible with the common market, although the same fusion would otherwise be prohibited (Horizontal Merger Guidelines, 2004). In practice, the defence was applied in the case of Kali und Salz/MdK/Treuhand (Commission Decision, 1993, Case IV/M.308, (1994) OJ L186/30, (1994) 4 CMLR 526), as well as in the case of BASF/Pantochim/Eurodial or the case of Newscorp/Telepiù (Case BASF / Pantochim / Eurodial IV/M.2314, IP/01/984; Case Newscorp / Telepiù IV/M.2876). In addition to horizontal fusions, there are vertical and conglomerate fusions, which are more closely regulated by the Guidelines on the assessment of non-horizontal fusions in accordance with the Council Regulation on the Control of Concentrations between Enterprises - hereinafter referred to as GNF (GNF, 2008). Although non-horizontal fusions are less dangerous for competitive processes, they can also be detrimental to competition on certain occasions.

\section{Vertical concentrations}

Unlike horizontal concentrations, vertical concentrations take place between the market levels of the chain of production, that is, the companies that relate to each other as buyer and seller, through which competitors in the downstream market can restrict access to key markets, which is a major threat to competition. Vertical concentrations represent one of the groupings for the non-horizontal fusions mentioned above. According to the GNF, there are two ways in which non-horizontal fusions can impede effective competition: 
non-coordinated effects and coordinated effects. Uncoordinated effects occur when non-horizontal fusions lead to foreclosure that is, preventing rivals from accessing the supply or the market. The coordinated effects are being altered by the very nature of competition that existed before the fusion, as companies will now have a much greater incentive to raise prices and, in general, disrupt competitive relationships (GNF, 2008, art.17-19). In this situation, the Commission will also, when assessing compatibility, rely on the market share of the new entity resulting from the fusion in question. The merger in question will be allowed if the newly acquired entity's market share is below $30 \%$. These are only starting indicators in the assessment, not legal assumptions (GNF, 2008, art. 23-27). In terms of uncoordinated effects, namely, denial of market access, two manifestations of this behaviour can be distinguished: when the fusion in question can increase the costs of competitors in the downstream market by restricting their access to important input and when fusion with rivals restricts access to consumers. In both cases, it is not necessary for rivals to be completely driven out of the relevant market, but it is important whether the increase in input costs will eventually lead to higher prices for consumers or not (GNF, 2008. Art.30-31, and art.58). For coordinated effects, it should be noted that such market coordination occurs in a situation where competitors are able to identify and pursue general objectives without concluding an agreement or resorting to consensual practices within the meaning of Article 81 of the Treaty. Certain conditions must be met here for coordination to be sustainable (GNF, 2008, art.80-81). Vertical fusion makes it easier to achieve behavioural coordination, since there will be fewer participants in the relevant market, it makes the coordination easier (GNF, 2008, art.82-85). It is particularly important to emphasize that this type of concentration enables the newly created entity to access sensitive information about rivals, especially if it is a downstream market (GNF, 2008, art. 86).

\section{Conglomerate concentrations}

Conglomerate concentrations involve mergers between companies operating in closely related markets, with no touch points prior to the merger. Here again, the Commission will pay attention to both the positive effects of the fusion in question and its negative anti-competitive effects. As with horizontal and vertical fusions, so with this form of concentration, there are so-called uncoordinated effects, expressed through foreclosure, for which "tied-trade practice" is the main instrument. Of course, the practice of tied trade (through whatever form it is expressed) will not always be impermissible, but in certain situations it will have a distinct anti-competitive effect. Here, too, the Commission must examine whether the newly created entity has the ability to exclude rivals, whether there is a corresponding economic interest, and whether such practices will have adverse effects on competition, thereby harming consumers (GNF, 2008, art.91). In order to be able to exclude competitors, a new company must possess a significant degree of market power (GNF, 2008, art.99). The exclusion of competitors through the practice of tied trade will be facilitated if a large circle of consumers buy both products in a 'bundle' rather than an individual product (GNF,2008, art.100). The Commission will consider whether there are opportunities for competitors to defend 
themselves against the new entity's business strategy. Thus, in the case of GE/Amersha, they took the standpoint that there was no risk of foreclosure of competitors by the practice of tied trading due to the fact that competing companies were pointing out very attractive offers to consumers (Case COMP/M. 3304-GE/Amersham, 2004). A tied trading strategy, if profitable, will be tempting for an entity. However, the Commission will also take into account other factors, such as: the ownership structure of the merged entity, the type of strategy adopted in the market in the past and the content of internal strategic documents - business plans and the like (GNF, 2008, art.94). The Commission rightly considers that conglomerate fusions can contribute to cost reductions, since it is sometimes much better for consumers to sell certain products in a "package" than separately. This is only a rebuttable assumption given the fact that sometimes identical benefits can be realized without resorting to tied trade (GNF, 2008, art. 118). With regard to the coordinated effects of mutatis mutandis, what is contained in the Horizontal Fusion Guidelines applies (GNF, 2008, art.119-121).

\section{The solutions provided by other provisions of EU law}

Should the Commission consider that the concentration in question is likely to be incompatible with the common market, the parties to the concentration may propose modifications to their concentration plan and offer certain obligations to the Commission. To this end, the Commission has issued the relevant Guidelines governing these issues (hereinafter: the Guidelines on Solutions) (Commission Notice, 2004). The Guideline states that a major distinction can be made between structural solutions and commitments that relate to the future behaviour of a fusion entity. In terms of structural solutions, the most prevalent are those consisting of the removal of a branch or production facilities. On the other hand, obligations relating to future behaviour will only apply in exceptional situations, where their usability is ensured by implementation and control. However, it must be said that it is very difficult to control their implementation (Commission Notice, 2004, art. 17). In addition to seeking to regulate all matters of Community acquis, practice sometimes denies the solutions contained in legal acts. Thus, in the case of Schneider/Legrand, the Commission prohibited concentration in holding that the proposed commitments were too complex and inefficient to ensure effective competition was maintained (Case COMP/M, 2282.). In order to preserve the effect of the "cure", obligations will be imposed on the merging entity that it cannot acquire influence over all or part of the separate business for a period of ten years, with the Commission being able to mitigate the obligation already imposed (Guidance on solutions, art. 43). An effective 'remedy' for the elimination of competition hazards may be considered to be the alteration or cancellation of existing exclusive contracts, which may lead to the elimination of competitors, but these acts may not constitute a 'screen' for the effective preservation of exclusivity (Guidance on solutions, Art. 68.). The parties to the concentration may also use other means to prevent the concentration from being declared incompatible with the common market. They may promise to refrain from certain behaviours that could jeopardize competition. However, 
it is difficult to control the implementation of these solutions, so the Commission will only examine non-structural remedies in exceptional circumstances (Guidance on solutions, art. 71). Finally, the parties to the concentration may also offer the socalled 'remedies packages', which cover both 'divestiture' and certain acts to which the parties to the concentration commit themselves. Even in such cases, in practice, the Commission has accepted alternative "'packages", that is, alternative solutions that would be implemented if the original solution proposed by the parties did not produce the expected competitive effects (Case IV/M.2337, IP/01/1136).

\section{Conclusion}

Based on the presentations in this research paper, in addition to identifying some of the basic rules used to solve the problem in question in the European Union market, it is also noted that the concentrations have a dual character, i.e. that concentrations, on one hand, can be a shield against external competition, while on the other hand they can distort competition in the common market. It is evident that the relevant acts clearly regulated the procedure for notification of concentration, and through the analysis of cases it was found that concentration in many procedures was prohibited, while in other cases the notification of concentration was rejected because it was not a concentration. What constitutes the essence of this research is the observation that the concentrations of companies are the most numerous cases for the protection of competition in the European Union market, and also in the market of third countries. Practice has shown that companies tend to hide the intended concentration from the eyes of the public and the Commission. However, high financial penalties were imposed after such cases were discovered. Conduct of foreign and domestic investors in the market of goods, services and capital are typical, regardless of whether they are engaged in agricultural or other economic activity, which can be justified by the argument that the same legal rules apply to the establishment and operation of business entities independent of the economic activity they perform.

\section{Conflict of interests}

The authors declare no conflict of interest.

\section{References}

1. Andrei, J. V., Popescu, G. H., Nica, E., \& Chivu, L. (2020). The impact of agricultural performance on foreign trade concentration and competitiveness: empirical evidence from Romanian agriculture. Journal of Business Economics and Management, 21(2), 317-343. https://doi.org/10.3846/jbem.2020.11988

2. Begović, B. (2002). Antimonopolska politika u SR Jugoslavij: Analiza postojećih tržišnih struktura $i$ antimonopolskih institucija, Centar za liberalno demokratske studije, Beograd, Srbija. [in English: Begovic, B. (2002). Antitrust Policy in FR Yugoslavia: Analysis of Existing Market Structures and Antitrust Institutions, Center for Liberal Democratic Studies, Belgrade, Serbia.]. 
3. Begović, B. (2014). Strukturne veze: širenje domena kontrole koncetracija $i$ posledica po pravnu sigurnost, Pravna sigurnost u uslovima tranzicije, Beograd. [in English: Begović, B. (2014). Structural links: expanding the domain of control of concentrations and consequences for legal security, Legal security in the conditions of transition, Belgrade.].

4. Cheminade, Y. (1970). Nature juridique de la fusion des personnes et des societes anonyimes, 23, Revue trimestrielle de droit commercial. [in English: Cheminade, Y. (1970). Legal nature of the merger of persons and anonymous companies, 23, Quarterly review of commercial law].

5. Chivu, L. (2019). Local entrepreneurship and social services in Romania. Territorial analysis. European Research on Management and Business Economics, 25(2), 79-86. https://doi.org/10.1016/j.iedeen.2019.04.001

6. Ciutacu, C., \& Chivu, L. (2014). About Agrarian structures and economic advantages. Procedia Economics and Finance, 8, 182-186. https://doi.org/10.1016/S22125671(14)00079-3

7. Gavrić Stepanović, S. (2000). Fuzija preduzeće u natimonopolskom pravu Evropske unije, 1-2, Pravo i privreda. [in English: Gavrić Stepanović, S. (2000). Fusion company in the antitrust law of the European Union, 1-2, Law and Economy.].

8. Jevremović Petrović, T. (2010). Prekogranična spajanja društava u pravu EU, Pravni fakultet, Univerzitet u Beogradu, Beograd, Srbija. [in English: Jevremović Petrović, T. (2010). Cross-border mergers of companies in EU law, Faculty of Law, University of Belgrade, Belgrade, Serbia.].

9. Mićović, M. (2010). Privredno pravo, Pravni fakultet, Univerzitet u Kragujevcu, Kragujevac, Srbija. [in English: Mićović, M. (2010). Commercial Law, Faculty of Law, University of Kragujevac, Kragujevac, Serbia.].

10. Odeny, J. A., Maingi, S., \& Kurauka, J. (2020). The role of procurement procedures in environmental management: A case study of classified hotels in Mombasa County, Kenya. Hotel and Tourism Management, 8(1), 11-23. https://doi.org/10.5937/ menhottur2001011A

11. Pantić, N., Milojević, I., \& Mićović, A. (2020). Menadžerska analiza mogućnosti upravljanja procesom privatizacije. Tehnika, 75(4), 493-497. [in English: Pantić, N., Milojević, I., \& Mićović, A. (2020). Managerial analysis of the possibilities of managing the privatization process. Technique, 75 (4), 493-497.] https://doi. org/10.5937/tehnika2004493P

12. Rakić, I. (2014). Primena propisa o kontroli koncetracija na strukturne veze osvrt na predlog Evropske komisije, 4-6, Pravo i privreda. [in English: Rakić, I. (2014). Application of regulations on control of concentrations on structural links - a review of the proposal of the European Commission, 4-6, Law and Economy.].

13. Spasić, I. (2007). Komunitarno pravo konkurencije. Strani pravni život: Teorija, zakonodavstvo, praksa, 1-2, 62-83. [in English: Spasić, I. (2007). Community competition law. Foreign Legal Life: Theory, Legislation, Practice, 1-2, 62-83.]. 
14. Spasić, V. (2017). Pravo intelektualne svojine, Pravni fakultet Univerziteta u Nišu, Centar za publikacije. [in English: Spasić, V. (2017). Intellectual Property Law, Faculty of Law, University of Nis, Publications Center.].

15. Stanivuković, M. (2009). Primena domaćih pravila o zaštiti konkurencije na pravne odnose sa međunarodnim elementom po uzoru na pravo Evropske zajednice. Anali pravnog fakulteta Univerziteta u Beogradu, 2, 110-1. [in English: Stanivuković, M. (2009). Application of domestic rules on protection of competition to legal relations with an international element modeled on European Community law. Annals of the Faculty of Law, University of Belgrade, 2, 110-1.].

16. Treaty on European Union and the Treaty on the Functioning of the European Union, 2010/C 83/01.

17. Vasiljević, M. (2004). Poslovno pravo, Udruženje pravnika u privredi SCG, Beograd, Srbija. [in English: Vasiljević, M. (2004). Business law, Association of Lawyers in the Economy of Serbia and Montenegro, Belgrade, Serbia.].

18. Case Steetly/Tarmac IV/M.180, 19924 CMLR 337. https://ec.europa.eu/ competition/mergers/cases/decisions/m180_9_en.pdf

19. Council Regulation (EC) No 139/2004 of 20 January 2004 on the control of concentrations between undertakings (the EC Merger Regulation) (Text with EEA relevance)

https://eur-lex.europa.eu/legal-content/EN/ALL/?uri=celex\%3A32004R0139

20. Case Newspaper Publishing IV/M.423, Regulation (EEC) no 4064/89 Merger procedure.

https://ec.europa.eu/competition/mergers/cases/decisions/m423_en.pdf

21. Case No IV/M.567 - Lyonnaise Des Eaux/Northumbrian Water, Regulation (EEC) no 4064/89, Merger Procedure https://ec.europa.eu/competition/mergers/cases/decisions/m567_en.pdf

22. Case British Aerospace/GEC Marconi, 1999, Official Journal of the European Union C241/8.https://eur-lex.europa.eu/legal-content/EN/TXT/?uri $=$ CELEX\%3A31999M1438

23. Case IV/M.784, (1997) OJ L174/47, Case T-22/97, Kesko Oy v. Commission (1999) ECR II-3755, (2000) 4 CMLR 335.

24. Commission Notice on a simplified procedure for treatment of certain concentrations under Council Regulation (EC) No 139/2004, Official Journal of the European Union 2005/C 56/04. https://eur-lex.europa.eu/legal-content/EN/TXT/PDF/?uri=CELEX:5201 $3 \mathrm{XC} 1214 \% 2802 \% 29 \&$ from $=\mathrm{EN}$

25. Commission Consolidated Jurisdictional Notice under Council Regulation (EC) No $139 / 2004$ on the control of concentrations between undertakings, Official Journal of the European Union C 95/1 https://eur-lex.europa.eu/legal content/EN/TXT/?ur $\mathrm{i}=\mathrm{CELEX} \% 3 \mathrm{~A} 52008 \mathrm{XC} 0416 \% 2808 \% 29$ 
26. Commission Notice on Case Allocation Under the Referral Rules of the Merger Regulation (2005) OJ C56/2.

https://eur-lex.europa.eu/legal-content/EN/TXT/PDF/?uri=CELEX:52005XC0305 (01)\&from $=\mathrm{EN}$

27. Commission Decision of 8 June 1994 declaring the compatibility of a concentration with the common market (Case No IV/M. 269 - Shell/Montecatini), Official Journal of the European Union 94/811/EC.

https://eur-lex.europa.eu/legal-content/BG/TXT/?uri=CELEX:31994D0811

28. Commission Decision of 22 July 1992 relating to a proceeding under Council Regulation (EEC) No 4064/89 (Case No IV/M.190 - Nestlé/Perrier), Official Journal of the European Union, 92/553/EEC.

https://eur-lex.europa.eu/legal-content/EN/TXT/?uri=CELEX\%3A31992D0553

29. Commission Decision declaring a concentration compatible with the common market and the functioning of the EEA Agreement (Case No IV/M.877 - Boeing/ McDonnell Douglas), 97/816/EC

https://eur-lex.europa.eu/legal-content/EN/TXT/?uri=CELEX\%3A31997D0816

30. Commission Decision relating to a proceeding pursuant to Council Regulation (EEC) No 4064/89 (Case No IV/M.308 Kali- Salz/MdK/Treuhand) (Text with EEA relevance), 94/449/EC https://eur-lex.europa.eu/legal-content/HR/TXT/?uri=CELEX\%3A31994D0449

31. Case COMP/M. 3304-GE/Amersham (2004), https:/ec.europa.eu/competition/ mergers/cases/decisions/m3304_en.pdf

32. Commission Notice on remedies acceptable under Council Regulation (EC) no. 139/2004 and under Commission Regulation (EC) no. 802/2004 (2008/C 267/01) https://eurlex.europa.eu/LexUriServ/LexUriServ.do?uri=OJ:C:2008:267:0001:002 7:EN:PDF

33. EC Treaty 2002, Official Journal of the European Communitie C40E/181 http:// webcache.googleusercontent.com/search?q=cache: 1 FqmLgPM6kcJ:eurlex. europa.eu/LexUriServ/LexUriServ.do\%3Furi\%3DOJ:C:2002:040E:0181:0182:E $\mathrm{N}: \mathrm{PDF}+\& \mathrm{~cd}=1 \& \mathrm{hl}=\mathrm{hr} \& \mathrm{ct}=\mathrm{clnk} \& \mathrm{gl}=\mathrm{ba}$

34. Guidelines on the Method of Setting Fines Imposed Pursuant to Article 23(2)(A) of Regulation No. 1/2003, 2006, Official Journal of the European Union OJ C210/2 https://eurlex.europa.eu/LexUriServ/LexUriServ.do?uri=OJ:C:2006:210:0002:000 5:en:PDF

35. Guidelines on the assessment of non-horizontal mergers under the Council Regulation on the control of concentrations between undertakings, Official Journal of the European Union 2008/C 265/07.

https://eur-lex.europa.eu/legal-content/EN/TXT/PDF/?uri=CELEX:52008XC1018 (03)\&rid=6 
36. Horizontal Merger Guidelines, 2004, Official Journal of the European Union C31/5. https:/eur-lex.europa.eu/legal-content/EN/TXT/PDF/?uri=CELEX:52004XC0205(02 )$\&$ from $=\mathrm{EN}$

37. Horizontal Merger Guidelines, 2004, Official Journal of the European Union C31/5. https://eurlex.europa.eu/legalcontent/EN/TXT/PDF/?uri=CELEX:52004X $\mathrm{C} 0205(02) \&$ from $=\mathrm{EN}$

38. Regulation of contraction control between entrepreneurs, No. 139/2004, https://eur-lex.europa.eu/legal content/EN/ALL/?uri=celex\%3A32004R0139

39. Treaty on European Union and the Treaty on the Functioning of the European Union, 2010/C 83/01

https://eur-lex.europa.eu/resource.html?uri=cellar:6985a220-b291-422c-8e7ce2625a041d0d.0006.01/DOC_1\&format=PDF 